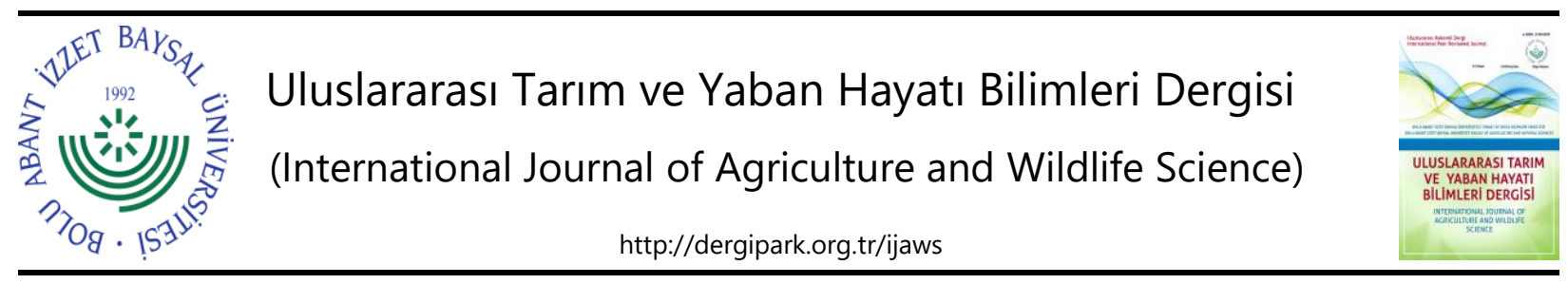

Rearch article

\title{
The Effect of Aminoethoxyvinylglycine (AVG) on Pre-harvest Fruit Drop and Fruit Quality in Red Chief and Braeburn Apple Cultivars
}

\author{
Emine Küçüker ${ }^{1}$ (D), Erdal Ağlar ${ }^{2 *}$
}

${ }^{1}$ Siirt University, Faculty of Agriculture, Department of Horticulture, Siirt, Turkey

${ }^{2}$ Sivas Cumhuriyet University Suşehri Timur Karabal Vocational School, Sivas,Turkey

Geliş tarihi (Received): 19.04.2021 Kabul tarihi (Accepted): 15.06.2021

\begin{abstract}
Keywords:
Malus comminus, fruit firmness starch index, retention force

*Corresponding Author erdalaglar@hotmail.com

Abstract. The study was carried out in 2017 in the semi-dwarf apple orchard established in 2010 in Kemalpaşa village in Tokat province in order to determine the effect of AVG application in different concentrations on the pre-harvest fruit drop and fruit quality of Red Chief and Braeburn apple cultivars. In the study, 7 years-old apple trees of Red Chief and Braeburn cultivars grafted on MM106 rootstock were used. AVG, at $0,75,150$ and $225 \mathrm{mg} \mathrm{L}^{-1}$ combined with a Regulaid' surfactant at $0.1 \%$ $\mathrm{V} / \mathrm{v}$, was applied to the trees before anticipated harvest. Fruit drop ratio, which varied depending on the cultivar, was lower in the AVG treated trees, and the effect of the application concentration was significant. AVG application was effective in maintaining the fruit retention force. The significant differences in fruit retention force occurred between application concentrations. It was determined that the the fruit retention force was higher in the fruits belonging to the Breaburn cultivar. The effect of AVG on fruit size, SSC pH and acidity rates varied depending on the variety. There was no significant differences in fruit firmness and starch index between cultivars. AVG application increased the fruit firmness and decreased the amount of starch both cultivar. As a result, of this study, it has been revealed that AVG can be used effectively in preventing pre-harvest fruit drop in Redchief ve Braeburn.
\end{abstract}

\section{Aminoethoxyvinylglycine (AVG) Uygulamasının Red Chief ve Braeburn Elma Çeşitlerinde Hasatönü Meyve Dökümü ve Meyve Kalitesi Üzerine Etkisi}

Anahtar kelimeler

Malus comminus, meyve eti sertliği, nişasta indeksi, kopma direnci
Özet. Farklı konsantrasyonlarda AVG uygulamasının Red Chief ve Braeburn elma çeşitlerinde hasatönü meyve dökümü ve meyve kalitesi üzerine etkisinin belirlenmesi amacıyla yürütülen bu çalışma Tokat ili Kemalpaşa köyünde 2010 yılında kurulmuş olan yarı bodur elma bahçesinde 2017 yılında yapıldı. Çalışmada MM106 anacı üzerine aşıı Red Chief ve Braeburn çeşitlerine ait 7-yaşı elma ağaçları kullanıldı. 0, 75, 150 ve $225 \mathrm{mg} \mathrm{L}^{-1}$ konsantrasyonlarda ve \%0.1 v / v 'de bir sürfaktan ile kombine edilen AVG, tahmini hasattan 4 hafta önce ağaçlara uygulandı. Çeşide bağlı olarak değişiklik gösteren hasat önü meyve dökümü AVG uygulanmış ağaçlarda daha düşüktü ve uygulama konsatrasyonun etkisi önemliydi. AVG uygulaması meyvede kopma direncinin muhafaza edilmesinde etkili olurken uygulama konsantrasyonları arasında da önemli farklılıklar meydana geldi. Breaburn çeşidine ait meyvelerde kopma direncinin daha yüksek olduğu belirlendi. AVG uygulaması meyvede büyüklük, SSC pH ve asitlik değerleri üzerine etkisi çeşide bağlı olarak farklılık gösterdi. Et sertliği ve nişasta indeksi açısından çeşitler arasında önemli bir faklılık oluşmadı AVG uygulaması meyve et sertliğini arttııırken, nişasta miktarını azalttı. Sonuç olarak bu çalışmadan elde edilen bulgular, AVG'nin Redchief ve Braeburn elma çeşitlerinde hasat önü dükümlerin önlenmesinde etkili bir şekilde kullanılabileceği ortaya koymuştur. 


\section{INTRODUCTION}

In apple, the pre-harvest fruit drop, which occurs before the fruit reaches the optimum size and color and causes significant economic losses is an important problem for apple growers (Greene, 2006). The pre-harvest fruit drop occur as a result of morphological, anatomical, genotypic and biochemical differentiations (Arseneault et al., 2016). The pre-harvest drop which are explained by events such as the cell differentiation, the response to developmental changes in metabolism, cell separation and the formation of a protective layer in the abscission zone (Estornell et al., 2013; Meir et al., 2019), are associated with the internal hormone balance in the fruit (Ozturk et al., 2019). The fruit drop reaching $50 \%$ in some cultivar varies depending on the cultivar, ecological factors (Basak and Buczek, 2010; Robinson et al., 2010) and cultural practices (Ward, 2004; Greene, 2006). However, it was suggested that the factors that affect the internal hormone balance, such as the fruit size (Dal Cin et al., 2007), the location of the fruit in the cluster (cyme) (Dal Cin et al., 2009; Miranda et al., 2005), the location of the fruit on the tree (Arseneault et al., 2016), the number of the seeds ( Estornell et al., 2013; Eccher et al., 2015; Ferrero et al., 2015), and the loss of xylem function (Drazeta et al., 2004; Miqueloto et al., 2014) may affect the fruit drop ratio.

Auxins and gibberellins, which affect plant growth and act as chemical messengers, prevent pre-harvest fruit drop while abscisic acid (ABA) and ethylene promote it (Addicott, 1982; Estornell et al., 2013). In studies conducted on apples and tomatoes, it was found that a decrease in the amount of auxin and an increase in the amount of ethylene in the fruit promoted the fruit drop (Thompson and Osborne, 1994; Bangerth, 2000; Hong et al., 2000; Vriezen et al., 2008). It had been seen that in particular, ethylene has been found to be closely related to abscission, and the internal ethylene concentration of non-abscissing fruit was higher than abscising fruit (Greene et al., 2014). Since the abscission and maturation events occur simultaneously, the biochemical role of ethylene in abscission is unclear, it is known that the process following the initiation of abscission is accelerated by ethylene (Arseneault et al., 2016). Due to the effect of the auxin-ethylene interaction on the fruit drop, the effects of the bioregulators such as naphthalene acetic acid (NAA) that promotes auxin concentration (Yuan and Carbaugh, 2007; Dal Cin et al., 2008) and AVG that inhibits ethylene increase (Byers, 1997; Greene and Schupp, 2004; Kang et al., 2007; Dal Cin et al., 2008; Yildiz et al., 2012; Ozturk et al., 2015; Aglar et al., 2016; Souza et al., 2019) on the pre-harvest fruit drop have been determined by previous studies. It has been reported that AVG is more effective than NAA in preventing pre-harvest fruit drop in apples (Greene et al., 1987, Yildiz et al., 2012). However, it has been suggested that the effectiveness of AVG varies according to the cultivar (Autio and Bramlage, 1982), the time (Chun et al., 1997) and the concentration of the application (Schupp and Greene, 2004). By considering this situation, in the study, it was aimed to determine the effect of the different doses of AVG on pre-harvest fruit drop and fruit quality of Red Chief and Braeburn apple cultivars.

\section{MATERIALS AND METHODS}

\section{Plant Material}

The study was carried out in 2017 in the semi-dwarf apple orchard established in 2010 in Kemalpaşa village in Tokat province $\left(40^{\circ} 20^{\prime} 02.19^{\prime \prime} \mathrm{N}\right.$ latitude and $36^{\circ} 28^{\prime} 30.11^{\prime \prime} \mathrm{E}$ longitude and $623 \mathrm{~m}$ above sea level). In the study, 7year-old Red Chief and Braeburn apple trees that were planted with $4 \times 2 \mathrm{~m}$ planting density, grafted on MM106 rootstock and applied Central Leader training system were used as plant material. The soil of the trial area has a clayey, sandy and silty structure. The experiments were laid out in a randomized complete-block design with three single-tree replications per treatment. The trees were blocked based on proximity in orchard and crop load. AVG ('ReTain'; Valent BioSciences Crop, Libertyville, II) at 0, 75, 150 and $225 \mathrm{mg} \mathrm{L}^{-1}$ combined with a Regulaid' surfactant [0.1\%, v v v $^{-1}$ (Kalo Inc., Overland Park, KS66211)] at 0.1\% v v v $^{-1}$, was applied 4 week (on 1 September 2017 in Red Chief and on 15 September 2017 in Breaburn) before anticipated harvest. Treatments were applied to run off with a low pressure hand sprayer. For each treatment, one tree was used in each block.

\section{Cumulative Drop Ratio (\%)}

The total number of fruit on the tree was determined one month before the harvest. Then, twice a week, the fruit dropped from the tree was counted. The number of the dropped fruit was taken from the total number of fruit and expressed in as \% per week.

\section{Fruit Retention Force}

The retention force of the fruit was measured by using fruit on branches $2 \mathrm{~m}$ high. The retention force of the fruit was measured in Newton (N) using a digital force meter (Troni HF-10, $100 \mathrm{~N}$, Taiwan) in the direction of the 
Küçüker and Ağlar, The Effect of Aminoethoxyvinylglycine (Avg) on Pre-Harvest Fruit Drop and Fruit Quality in Red Chief and Braeburn Apple Cultivars

fruit stem axis with the help of an aluminum apparatus prepared in accordance with the dimensional characteristics of the fruit (Polat et al., 2007).

\section{Fruit Size}

The fruit size was determined by measuring the diameter and weight of the fruit. The fruit diameter was determined by taking the average of the results obtained by measuring the fruit width and height using a digital caliper with $0.01 \mathrm{~mm}$ precision (Mitutoyo, Japan) and expressed in $\mathrm{mm}$. The weight of each fruit was measured with a digital scale (Radwag, Poland) with a sensitivity of $0.01 \mathrm{~g}$ and the fruit weight was determined by taking the average and expressed as $\mathrm{g}$.

\section{Soluble Solids Content, $\mathrm{pH}$ and Titratable Acidity}

The fruit was shredded with a blender and made homogeneous, and the obtained homogenate was passed through a cheesecloth and fruit juice was obtained. Sufficient amount of juice was dropped into a digital refractometer (PAL-1, McCormick Fruit Tech., Yakima, Wash.) for the measurement of SSC and the value on the screen was recorded as \%. $\mathrm{pH}$ was measured with a $\mathrm{pH}$ meter (Hanna, model HI9321). For titratable acidity (TA) measurements, $10 \mathrm{ml}$ of the obtained juice was taken and $10 \mathrm{ml}$ of distilled water was added on it. Then, samples were expressed in terms of malic acid ( $\mathrm{g}$ malic acid $100 \mathrm{ml}^{-1}$ ) based on the amount of $\mathrm{NaOH}$ spent in titration with $0.1 \mathrm{~N}$ sodium hydroxide until $\mathrm{pH} 8.1$ was reached.

\section{Fruit Firmness}

For the fruit firmness, the fruit peel was cut at three different locations on the equatorial region of the fruit and measured as $\mathrm{kg}$ with the $11.1 \mathrm{~mm}$ tip of the penetrometer (Effegi brand, model FT-327; MoCormick Fruit Tech, Yakima, WA), then the values have been translated in Newton (N).

\section{Starch Index}

The fruit were divided into 2 equal parts, a circular slice with a width of approximately $1 \mathrm{~cm}$ was taken from the part on the side of the stem and $0.5 \%$ iodized potassium iodide (IKI) solution was applied on this circular slice until the surface was wet. After 5 minutes, the starch containing region was dyed dark blue and evaluated according to the scale prepared by Blanpied and Silsby (1992) ( 1 to 8 scale range, $1=100 \%$ starch, $8=0 \%$ starch).

\section{Statistical Analysis}

After analyzing the data obtained from the research with analysis of variance, the level of significance between the treatments means was determined by the Tukey multiple comparison test. The statistical analysis was performed using the SAS package program (SAS 9.1 version, USA). The significance level was taken into account as $p<0.05$ in statistical analysis and interpretation of the results.

\section{RESULTS}

\section{Cumulative Drop Ratio (\%)}

The weekly fruit drop ratio rate increased in directly proportional to the fruit ripening stage. Considering the control application $\left(0 \mathrm{mg} \mathrm{L}^{-1}\right)$ in Red Chief cultivar, it was determined that the fruit drop ratio was $19.80 \%$ in the first week (16 ${ }^{\text {th }}$ Semtember), but in total, $56.60 \%$ of the fruit was dropped. It was observed that the fruit drop in AVG applied trees was lower in all measurement periods. However, the cumulative fruit drop ratio varied depending on the AVG application concentration. When the cumulative fruit drop ratio of both cultivars were evaluated, the highest value was obtained with the control application while the drop ratio in the fruit decreased with the increase of AVG concentration. The lowest fruit drop ratio was recorded in $225 \mathrm{mg} \mathrm{L}^{-1} \mathrm{AVG}$ applied trees. There were the significant differences between the cultivars in terms of the fruit drop ratio. In the first two measurement periods, the fruit drop was higher in Breaburn cultivar while the total fruit drop ratio was higher in Red Chief cultivar. Considering the cumulative fruit drop ratio, it can be said that AVG application is more effective in Red Chief cultivar. When the control and $225 \mathrm{mg} \mathrm{L}^{-1}$ AVG applications were compared in both cultivars, the fruit drop in Red Chief cultivar decreased by $44 \%$ with $225 \mathrm{mg} \mathrm{L}^{-1}$ AVG application while the decrease was $33 \%$ in Breaburn cultivar (Table 1). 


\section{Fruit Retention Force $(\mathrm{N})$}

Considering the control application, it was observed that the fruit retention force towards the harvest decreased as a natural result. While AVG application was effective in maintaining the retention force in fruit, the significant differences occurred between application concentrations. In the first two weeks, the retention force of AVG applied fruit generally decreased while the fruit retention force increased with the AVG application in the measurements made in the third and fourth weeks, and the statistically significant changes occurred depending on the application concentration. When the fruit retention force was compared by considering the Red Chief cultivar and the control application $\left(0 \mathrm{mg} \mathrm{L}^{-1}\right)$, the fruit retention force, which was $16.51 \mathrm{~N}$ in the first measurement period with the control application, was recorded as $15.18 \mathrm{~N}$ in the last measurement period. In the $125 \mathrm{mg} \mathrm{L}^{-1}$ AVG applied fruit, the fruit retention force was $19.05 \mathrm{~N}$ in the first measurement period while it rised to 26.89 Newtons in the last measurement period. It was determined that the fruit retention force varied depending on the cultivar, and the retention force was higher in the fruit of the Breaburn cultivar. However, in the last measurement period, the retention force was found to be higher in the fruit of the Red Chief variety, which were applied $125 \mathrm{mg} \mathrm{L}^{-1}$ and $250 \mathrm{mg} \mathrm{L}^{-1}$ AVG. Considering these data, it can be said that $125 \mathrm{mg} \mathrm{L}^{-1}$ and $250 \mathrm{mg} \mathrm{L}^{-1}$ AVG applications are more effective on the fruit retention force in Red Chief cultivar (Table 1).

Table 1. Effect of different concentrations of AVG on fruit drop ratio and fruit retention of 'Red Chief' and Breaburn apples. Çizelge 1. Farklı dozlardaki AVG nin Red Chief ve Breaburn elma çeşitlerinde meyve dökümü ve kopma direnci üzerine etkisi.

\begin{tabular}{|c|c|c|c|c|c|c|c|c|}
\hline \multirow{3}{*}{$\begin{array}{l}\text { Treatment } \\
\left(\mathrm{mg} \mathrm{L}^{-1}\right)\end{array}$} & \multicolumn{8}{|c|}{ Fruit drop ratio (\%) } \\
\hline & \multicolumn{2}{|c|}{16 September } & \multicolumn{2}{|c|}{23 September } & \multicolumn{2}{|c|}{30 September } & \multicolumn{2}{|c|}{07 October } \\
\hline & $\mathrm{RC}$ & BB & $\mathrm{RC}$ & $\mathrm{BB}$ & $\mathrm{RC}$ & $\mathrm{BB}$ & $\mathrm{RC}$ & $\mathrm{BB}$ \\
\hline 0 & $19.80 \mathrm{Ba}$ & $21.15 \mathrm{Aa}$ & $35.40 \mathrm{Ba}$ & $37.18 \mathrm{Aa}$ & 45.10Aa & $42.76 \mathrm{Ba}$ & $56.60 \mathrm{Aa}$ & $53.24 \mathrm{Ba}$ \\
\hline 75 & $18.71 \mathrm{Ba}$ & $20.86 \mathrm{Aa}$ & $28.00 \mathrm{Bb}$ & $30.22 \mathrm{Ab}$ & $31.00 \mathrm{Bb}$ & $34.17 \mathrm{Ab}$ & $38.20 \mathrm{Bb}$ & $43.17 \mathrm{Ab}$ \\
\hline 125 & $17.16 \mathrm{Bb}$ & $18.73 \mathrm{Ab}$ & $22.70 \mathrm{BC}$ & $25.12 \mathrm{Ac}$ & $31.60 \mathrm{Ab}$ & $31.16 \mathrm{Ac}$ & $36.60 \mathrm{Bb}$ & $42.10 \mathrm{Ab}$ \\
\hline 225 & $16.15 \mathrm{Bb}$ & $18.02 \mathrm{Ab}$ & $24.00 \mathrm{Ab}$ & $22.14 \mathrm{BC}$ & $31.20 \mathrm{Ab}$ & $30.24 A c$ & $31.80 \mathrm{BC}$ & $35.80 \mathrm{Ac}$ \\
\hline \multirow{3}{*}{$\begin{array}{l}\text { Treatment } \\
\left(\mathrm{mg} \mathrm{L}^{-1}\right)\end{array}$} & \multicolumn{8}{|c|}{$\begin{array}{l}\text { Fruit retention force }(\mathrm{N}) \\
\end{array}$} \\
\hline & \multicolumn{2}{|c|}{16 September } & \multicolumn{2}{|c|}{23 September } & \multicolumn{2}{|c|}{30 September } & \multicolumn{2}{|c|}{07 October } \\
\hline & $\mathrm{RC}$ & BB & $\mathrm{RC}$ & BB & RC & BB & RC & BB \\
\hline 0 & $16.51 \mathrm{Bb}$ & $20.10 A c$ & $16.50 \mathrm{BC}$ & $19.04 \mathrm{Ac}$ & $16.18 \mathrm{BC}$ & $19.22 \mathrm{Ac}$ & $15.78 \mathrm{Ac}$ & $16.48 \mathrm{Ac}$ \\
\hline 75 & $18.54 \mathrm{Ba}$ & 23.27Ab & $18.61 \mathrm{Aa}$ & $19.42 \mathrm{Ab}$ & $19.40 \mathrm{Ba}$ & $22.14 \mathrm{Ab}$ & $17.38 \mathrm{Bbc}$ & $19.06 \mathrm{Ab}$ \\
\hline 125 & $19.05 \mathrm{Ba}$ & $23.86 \mathrm{Ab}$ & $18.00 \mathrm{Ba}$ & $23.65 \mathrm{Aa}$ & $17.60 \mathrm{Bb}$ & $23.09 \mathrm{Ab}$ & $26.89 A a$ & $23.76 \mathrm{Ba}$ \\
\hline 225 & $18.92 \mathrm{Ba}$ & $27.21 \mathrm{Aa}$ & 17.10Bb & $20.68 \mathrm{Ab}$ & $16.61 \mathrm{Bb}$ & $28.21 \mathrm{Aa}$ & 24.66Aab & 22.47Bab \\
\hline
\end{tabular}

RC: Redchief, BB: Breaburn. Means with the same lowercase letter in same columns do not differ according to Tukey's test at $p<0.05$. The same capital letter expreses the difference between the cultivars. Means with the same capital letter in same line do not differ according to Tukey's test. However, the evaluation will be made between cultivars. In other words, the data for each measurement period will be evaluated among themselves.

\section{Fruit Size}

Considering the last measurement period ( $7^{\text {th }}$ October), it was determined that there were the significant differences between cultivar in fruit size determined by measuring fruit weight and diameter, and Breabun cultivar had larger fruit. AVG application affected the fruit weight. In both cultivar, the highest fruit weight values were recorded with $225 \mathrm{mg} \mathrm{L}^{-1}$ AVG applied trees. There were the significant differences between application in the Red Chief cultivar, and the lower weight fruit were obtained with the control application. However, in Breaburn cultivar, the difference between the applications was generally not significant, and the smallest fruit were harvested on $125 \mathrm{mg} \mathrm{L}^{-1} \mathrm{AVG}$ applied trees (Table 2).

Table 2. Effect of different concentrations of AVG on fruit size of 'Red Chief' and Breaburn apples.

Çizelge 2. Farklı dozlardaki AVG nin Red Chief ve Breaburn elma çeşitlerinde meyve büyüklügü üzerine etkisi.

\begin{tabular}{|c|c|c|c|c|c|c|c|c|}
\hline \multirow{3}{*}{$\begin{array}{l}\text { Treatment } \\
\left(\mathrm{mg} \mathrm{L}^{-1}\right)\end{array}$} & \multicolumn{8}{|c|}{ Fruit weight (g) } \\
\hline & \multicolumn{2}{|c|}{16 September } & \multicolumn{2}{|c|}{23 September } & \multicolumn{2}{|c|}{30 September } & \multicolumn{2}{|l|}{07 October } \\
\hline & $\mathrm{RC}$ & BB & $\mathrm{RC}$ & BB & $\mathrm{RC}$ & BB & $\mathrm{RC}$ & BB \\
\hline 0 & $160.00 \mathrm{Bb}$ & $180.45 A c$ & $165.83 \mathrm{Bb}$ & $186.35 \mathrm{Ab}$ & $175.00 \mathrm{Bb}$ & 197.18Ab & 187.66Bc & 210.62Aa \\
\hline 75 & 161.24Bb & 195.01Aa & 167.37Bb & 199.91Aa & $177.11 \mathrm{Bb}$ & 210.66Aa & 189.30Bbc & 213.19Aa \\
\hline 125 & $162.18 \mathrm{Bb}$ & 193.79Aa & $175.93 \mathrm{Bb}$ & $200.91 \mathrm{Aa}$ & $188.84 \mathrm{Ba}$ & 205.60Aab & 196.23Bb & $206.83 \mathrm{Ab}$ \\
\hline
\end{tabular}


Küçüker and Ağlar, The Effect of Aminoethoxyvinylglycine (Avg) on Pre-Harvest Fruit Drop and Fruit Quality in Red Chief and Braeburn Apple Cultivars

Table 2. Continue.

Çizelge 2. Devamı.

\begin{tabular}{|c|c|c|c|c|c|c|c|c|}
\hline \multirow{3}{*}{$\begin{array}{l}\text { Treatment } \\
\left(\mathrm{mg} \mathrm{L}^{-1}\right)\end{array}$} & \multicolumn{8}{|c|}{ Fruit weight (g) } \\
\hline & \multicolumn{2}{|c|}{16 September } & \multicolumn{2}{|c|}{23 September } & \multicolumn{2}{|c|}{30 September } & \multicolumn{2}{|c|}{07 October } \\
\hline & $\mathrm{RC}$ & BB & $\mathrm{RC}$ & BB & RC & BB & RC & BB \\
\hline 225 & $175.40 \mathrm{Ba}$ & 188.37Ab & $185.66 \mathrm{Aa}$ & $188.46 \mathrm{Ab}$ & $190.29 \mathrm{Ba}$ & $210.77 \mathrm{Aa}$ & $231.07 \mathrm{Aa}$ & $214.08 \mathrm{Ba}$ \\
\hline \multirow{3}{*}{$\begin{array}{l}\text { Treatment } \\
\left(\mathrm{mg} \mathrm{L}^{-1}\right)\end{array}$} & \multicolumn{8}{|c|}{ Fruit diameter $(\mathbf{m m})$} \\
\hline & \multicolumn{2}{|c|}{16 September } & \multicolumn{2}{|c|}{23 September } & \multicolumn{2}{|c|}{30 September } & \multicolumn{2}{|l|}{07 October } \\
\hline & $\mathrm{RC}$ & BB & $\mathrm{RC}$ & BB & $\mathrm{RC}$ & $\mathrm{BB}$ & $\mathrm{RC}$ & $\mathrm{BB}$ \\
\hline 0 & $76.45 \mathrm{Aa}$ & $70.50 \mathrm{Ba}$ & $71.36 \mathrm{Aa}$ & 73.60Aab & $70.06 \mathrm{Ba}$ & $75.64 \mathrm{Aa}$ & 73.44Aa & $75.22 \mathrm{Aa}$ \\
\hline 75 & 71.98Aa & $70.12 \mathrm{Aa}$ & $70.82 \mathrm{Ba}$ & 76.48Aa & $62.08 \mathrm{Bb}$ & $67.82 \mathrm{Ab}$ & $64.38 \mathrm{Bb}$ & $72.33 \mathrm{Aa}$ \\
\hline 125 & 72.77Aa & $68.68 \mathrm{Aa}$ & 67.07Aa & 69.79Ab & 66.03Bab & 73.30Aa & 66.13Bab & 71.49Aa \\
\hline 225 & $72.06 \mathrm{Aa}$ & 69.67Aa & $70.72 \mathrm{Aa}$ & $69.21 \mathrm{Ab}$ & $67.60 \mathrm{Ba}$ & $72.42 \mathrm{Aa}$ & 69.23Bab & $74.55 \mathrm{Aa}$ \\
\hline
\end{tabular}

RC: Redchief, BB: Breaburn. Means with the same lowercase letter in same columns do not differ according to Tukey's test at $p<0.05$. The same capital letter expreses the difference between the cultivars. Means with the same capital letter in same line do not differ according to Tukey's test. However, the evaluation will be made between cultivars. In other words, the data for each measurement period will be evaluated among themselves.

\section{Soluble Solids Content, pH and Titratable Acidity}

As maturity progressed in the fruit, it was determined that there was an increase in the amount of SSC but a decrease in the last measurement period (7th October). It was observed that the amount of SSC of the fruit usually varied depending on the cultivar, and the fruit of Breaburn cultivar had a higher SSC ratio. It can be said that AVG application affects the amount of SSC in fruit and the ratio of SSC is generally lower in AVG applied fruit (Table 3).

Table 3. Effect of different concentrations of AVG on SSC, pH and titratable acidity of 'Red Chief' and Breaburn apples . Çizelge 3. Farklı dozlardaki AVG nin Red Chief ve Breaburn elma çeşitlerinde SÇKM, titreedilebilir asitlik ve pH üzerine etkisi.

\begin{tabular}{|c|c|c|c|c|c|c|c|c|}
\hline \multirow{3}{*}{$\begin{array}{l}\text { Treatment } \\
\left(\mathrm{mg} \mathrm{L}^{-1}\right)\end{array}$} & \multicolumn{8}{|c|}{ Soluble solids content (\%) } \\
\hline & \multicolumn{2}{|c|}{16 September } & \multicolumn{2}{|c|}{23 September } & \multicolumn{2}{|c|}{30 September } & \multicolumn{2}{|c|}{07 October } \\
\hline & $\mathrm{RC}$ & $\mathrm{BB}$ & $\mathrm{RC}$ & $\mathrm{BB}$ & $\mathrm{RC}$ & $\mathrm{BB}$ & $\mathrm{RC}$ & BB \\
\hline 0 & $11.93 \mathrm{Ba}$ & $13.21 \mathrm{Aa}$ & $12.98 \mathrm{Ba}$ & $13.55 \mathrm{Aa}$ & 13.13Ba & $13.83 \mathrm{Aa}$ & $12.35 \mathrm{Aa}$ & 12.07Aa \\
\hline 75 & $11.68 \mathrm{Aa}$ & $11.99 \mathrm{Ab}$ & $12.27 \mathrm{Bb}$ & 13.32Aa & $12.48 \mathrm{Bb}$ & $13.09 \mathrm{Ab}$ & 12.16Aa & $11.53 \mathrm{Bb}$ \\
\hline 125 & $11.15 \mathrm{Ab}$ & $11.53 \mathrm{Ab}$ & $12.20 \mathrm{Bb}$ & 13.89Aa & $12.55 \mathrm{Bb}$ & $13.23 \mathrm{Ab}$ & $12.30 \mathrm{Aa}$ & $11.70 \mathrm{Bb}$ \\
\hline 225 & $10.40 \mathrm{Ab}$ & $10.76 \mathrm{Ab}$ & $12.00 \mathrm{Bb}$ & $12.88 \mathrm{Ab}$ & $12.33 \mathrm{Ab}$ & $12.31 \mathrm{Ac}$ & $10.88 \mathrm{Bb}$ & 12.03Aa \\
\hline \multirow{3}{*}{$\begin{array}{l}\text { Treatment } \\
\left(\mathrm{mg} \mathrm{L}^{-1}\right)\end{array}$} & \multicolumn{8}{|c|}{ pH } \\
\hline & \multicolumn{2}{|c|}{16 September } & \multicolumn{2}{|c|}{23 September } & \multicolumn{2}{|c|}{30 September } & \multicolumn{2}{|c|}{07 October } \\
\hline & $\mathrm{RC}$ & $\mathrm{BB}$ & $\mathrm{RC}$ & BB & $\mathrm{RC}$ & $\mathrm{BB}$ & $\mathrm{RC}$ & BB \\
\hline 0 & $4.28 \mathrm{Aa}$ & $3.74 \mathrm{Bb}$ & 4.36Aa & 3.94Ba & 4.49Aa & 3.95Bab & 4.54Aa & 3.89Ba \\
\hline 75 & 4.25Aa & 3.81Bab & 4.38Aa & 3.86Ba & 4.48Aa & 3.92Bb & $4.41 \mathrm{Ab}$ & 3.96Ba \\
\hline 125 & $4.26 \mathrm{Aa}$ & 3.89Ba & 4.40Aa & 3.93Ba & $4.43 \mathrm{Ab}$ & 3.98Ba & 4.49Aab & 3.90Ba \\
\hline 225 & $4.28 \mathrm{Aa}$ & 3.88Ba & $4.41 \mathrm{Aa}$ & $3.85 \mathrm{Ba}$ & $4.51 \mathrm{Aa}$ & 3.97Ba & $4.56 \mathrm{Aa}$ & 3.86Ba \\
\hline \multirow{3}{*}{$\begin{array}{l}\text { Treatment } \\
\left(\mathrm{mg} \mathrm{L}^{-1}\right)\end{array}$} & \multicolumn{8}{|c|}{ Titratable acidity (g malic acid $100 \mathrm{~mL}^{-1}$ ) } \\
\hline & \multicolumn{2}{|c|}{16 September } & \multicolumn{2}{|c|}{23 September } & \multicolumn{2}{|c|}{30 September } & \multicolumn{2}{|c|}{07 October } \\
\hline & $\mathrm{RC}$ & $\mathrm{BB}$ & $\mathrm{RC}$ & BB & $\mathrm{RC}$ & $\mathrm{BB}$ & $\mathrm{RC}$ & $\mathrm{BB}$ \\
\hline 0 & $0.20 \mathrm{BC}$ & $0.33 \mathrm{Aa}$ & $0.23 \mathrm{Ba}$ & $0.45 \mathrm{Aa}$ & $0.23 \mathrm{Bb}$ & $0.47 \mathrm{Aa}$ & $0.25 \mathrm{Bb}$ & $0.46 \mathrm{Aa}$ \\
\hline 75 & $0.23 \mathrm{Bb}$ & $0.35 \mathrm{Aa}$ & $0.26 \mathrm{Ba}$ & $0.43 \mathrm{Aa}$ & $0.26 \mathrm{Ba}$ & $0.42 \mathrm{Ab}$ & $0.27 \mathrm{Bb}$ & $0.38 \mathrm{Aab}$ \\
\hline 125 & $0.26 \mathrm{Ba}$ & $0.34 \mathrm{Aa}$ & $0.27 \mathrm{Ba}$ & $0.42 \mathrm{Aa}$ & $0.27 \mathrm{Ba}$ & $0.43 \mathrm{Ab}$ & $0.30 \mathrm{Ba}$ & $0.37 \mathrm{Ab}$ \\
\hline 225 & $0.22 \mathrm{Bb}$ & $0.33 \mathrm{Aa}$ & $0.25 \mathrm{Ba}$ & $0.44 \mathrm{Aa}$ & $0.26 \mathrm{Ba}$ & $0.42 \mathrm{Ab}$ & $0.29 \mathrm{Ba}$ & $0.36 \mathrm{Ab}$ \\
\hline
\end{tabular}

RC: Redchief, BB: Breaburn. Means with the same lowercase letter in same columns do not differ according to Tukey's test at $p<0.05$. The same capital letter expreses the difference between the cultivars. Means with the same capital letter in same line do not differ according to Tukey's test. However, the evaluation will be made between cultivars. In other words, the data for each measurement period will be evaluated among themselves.

It was determined that the effect of the cultivar in the amount of $\mathrm{pH}$ increasing with the progress of maturity was significant and the $\mathrm{pH}$ value of the fruit of Red Chief cultivar was higher. The effect of AVG application on $\mathrm{pH}$ varied depending on the measurement period and the cultivar. In the Red Chief, there was no effect of AVG application in the first and second measurement periods, in the third and the last measurement periods, $125 \mathrm{mg}$ 
Küçüker and Ağlar, The Effect of Aminoethoxyvinylglycine (Avg) on Pre-Harvest Fruit Drop and Fruit Quality in Red Chief and Braeburn Apple Cultivars

$\mathrm{L}^{-1}$ and $75 \mathrm{mg} \mathrm{L}^{-1}$ AVG applied fruit had lower $\mathrm{pH}$ values respectively. In the Breaburn cultivar, the $\mathrm{pH}$ value was lower only in $75 \mathrm{mg} \mathrm{L}^{-1}$ AVG applied fruit in the third measurement period (Table 3).

The acidity ratio in the fruit differed depending on the cultivar. The acidity ratio was higher in the fruit of the Breaburn cultivar. Again, the effect of AVG varied depending on the measurement period and cultivar. No AVG effect was noted in the second measurement period. In the first period, there was no difference between applications in Breaburn cultivar, it was determined that in the Red Chief cultivar, AVG-applied fruit had higher acidity and the most effective application was $125 \mathrm{mg} \mathrm{L}^{-1}$ AVG application. In the third and fourth measurement periods, the acidity ratio of the fruit of Red Chief cultivar increased with the AVG application while the acidity decreased in the Breaburn cultivar (Table 3).

\section{Fruit Firmness and Starch Index}

There was no statistically significant difference between cultivars in terms of the fruit firmness. The effect of AVG application on the fruit firmness was significant. The fruit with the highest the fruit firmness values were harvested in AVG-applied trees. Again, the effect of AVG varied depending on the application concentration. With the increase in the concentration, the fruit firmness increased. The highest values were recorded in fruit treated with $225 \mathrm{~m} \mathrm{~L}^{-1}$ AVG (Table 4).

The effect of the cultivar was not significant in starch index values. With the application of AVG, there was a decrease in the amount of starch of the fruit. However, it can be said that application concentration has not been significant in AVG effect. Considering the last measurement period, there was no difference between AVG application concentrations in the Breaburn cultivar while the amount of starch was higher in $225 \mathrm{mg} \mathrm{L}^{-1}$ AVG applied fruit in the Red Chief cultivar, and there was no statistically significant difference between this application and the control application (Table 4).

Table 4. Effect of different concentrations of AVG on fruit firmness and starch index of 'Red Chief' and Breaburn apples. Çizelge 4. Farklı dozlardaki AVG nin Red Chief ve Breaburn elma çeşitlerinde meyve eti sertliği ve nişasta indeksi üzerine etkisi.

\begin{tabular}{|c|c|c|c|c|c|c|c|c|c|}
\hline \multirow{3}{*}{$\begin{array}{l}\text { Treatment } \\
\left(\mathrm{mg} \mathrm{L}^{-1}\right)\end{array}$} & \multicolumn{9}{|c|}{ Fruit firmness $(\mathrm{N})$} \\
\hline & \multicolumn{2}{|c|}{16 September } & \multicolumn{2}{|c|}{23 September } & \multicolumn{2}{|c|}{30 September } & \multicolumn{3}{|c|}{07 October } \\
\hline & $\mathrm{RC}$ & BB & $\mathrm{RC}$ & $\mathrm{BB}$ & $\mathrm{RC}$ & BB & $\mathrm{RC}$ & & BB \\
\hline 0 & 7.48Ab & 8.01Ac & 7.34Ac & 8.00Ac & 7.12Ab & 7.70Ac & 7.10Ac & 7.00Ac & \\
\hline 75 & 7.67Aa & $8.10 A b$ & 7.56Aa & 8.05Ab & 7.43Aab & 8.00Ab & $7.38 \mathrm{Ab}$ & 7.96Ab & \\
\hline 125 & 7.60Aab & 8.46Aa & 7.49Aa & 8.39Ab & 7.51Aab & 8.29Ab & $7.28 \mathrm{Ab}$ & 8.26Aa & \\
\hline 225 & $7.58 \mathrm{Ab}$ & 8.47Aa & 7.46Ab & 8.45Aa & 7.74Aa & 8.42Aa & 7.63Aa & $8.41 \mathrm{Aa}$ & \\
\hline \multirow{3}{*}{$\begin{array}{l}\text { Treatment } \\
\left(\mathrm{mg} \mathrm{L}^{-1}\right)\end{array}$} & \multicolumn{9}{|c|}{ Starch index } \\
\hline & \multicolumn{2}{|c|}{16 September } & \multicolumn{2}{|c|}{23 September } & \multicolumn{2}{|c|}{30 September } & \multicolumn{3}{|c|}{07 October } \\
\hline & $\mathrm{RC}$ & $\mathrm{BB}$ & $\mathrm{RC}$ & BB & $\mathrm{RC}$ & $\mathrm{BB}$ & $\mathrm{RC}$ & & BB \\
\hline 0 & 6.77Aa & $6.67 \mathrm{Aa}$ & $6.25 \mathrm{Aa}$ & 5.56Aa & $6.50 \mathrm{Aa}$ & 7.00Aa & $6.50 \mathrm{Aa}$ & 6.45Aa & \\
\hline 75 & $5.87 \mathrm{Ab}$ & 5.67Aab & $5.21 \mathrm{Ab}$ & 5.22Aa & $5.83 \mathrm{Ab}$ & 6.67Aa & $5.25 \mathrm{Ab}$ & $6.11 \mathrm{Ab}$ & \\
\hline 125 & $5.45 \mathrm{Ab}$ & $4.33 \mathrm{BC}$ & $5.82 \mathrm{Ab}$ & $5.12 a$ & $5.58 \mathrm{Ab}$ & $6.55 \mathrm{Ab}$ & $5.75 \mathrm{Ab}$ & $6.10 \mathrm{Ab}$ & \\
\hline 225 & $5.88 \mathrm{Ab}$ & $5.55 \mathrm{Ab}$ & 5.77Ab & $4.44 \mathrm{Ba}$ & $5.66 \mathrm{Ab}$ & $6.00 \mathrm{Ab}$ & $6.00 \mathrm{Aa}$ & $6.00 \mathrm{Ab}$ & \\
\hline
\end{tabular}

RC: Redchief, BB: Breaburn. Means with the same lowercase letter in same columns do not differ according to Tukey's test at $p<0.05$. The same capital letter expreses the difference between the cultivars. Means with the same capital letter in same line do not differ according to Tukey's test. However, the evaluation will be made between cultivars. In other words, the data for each measurement period will be evaluated among themselves.

\section{DISCUSSION}

In apples, pre-harvest fruit drop, which sometimes rises up to $50 \%$ and causes significant income losses (Greene, 2006), occur as a result of morphological, anatomical, genetic and biochemical differences (Michelle et al., 2016). These fruit drop (Estornell et al., 2013; Meir et al., 2019), which are explained by events such as cell differentiation in the abscission zone, response to developmental changes in metabolism, cell separation and the formation of a protective layer (Estornell et al., 2013; Meir et al., 2019) are related to the internal hormone balance in the fruit and especially ethylene (Ozturk et al., 2019). The plant hormones that affect plant growth, act as chemical messengers and change growth in low concentration (Davies, 2010) have significant role in pre-harvest fruit drop. It is suggested that auxin and gibberellin inhibit the fruit drop, but ethylene and abscisic acid (ABA) promote (Addicott, 1982; Estornell et al., 2013). Therefore, the use of the plant growth regulators that inhibit ethylene synthesis in the plant has been the focus to prevent fruit drop in apples (Michelle et al., 2016). The 
physiological events regulated by ethylene, such as ethylene synthesis and therefore pre-harvest fruit drop, may be prevented by aminoethoxyvinylglycine (AVG) binding to the active site of enzyme 1-aminocyclopropane-1carboxylate synthase (ACS) and inhibiting theisis of ethylene immediate precursor aminocyclopropane- 1carboxylate (ACC), which is thereafter converted into ethylene by ACC oxidase (ACO) (Huai et al., 2001). AVG, which inhibits the increase in internal ethylene, has been shown to be effective in preventing pre-harvest fruit drop (Byers, 1997; Greene and Schupp, 2004; Kang et al., 2007; Dal Cin et al., 2008; Robinson et al., 2010; Yildiz et al., 2012; Ozturk et al., 2015; Aglar et al., 2016; Souza et al., 2019). In the study, smilarly with these results, AVG application had a positive effect on preserving the fruit retention force and thus preventing fruit drop, but this effect varied depending on the cultivar and application concentration. As a matter of fact, (McFadyen et al., 2012; Ozkan et al., 2016) have reported that the effect of AVG on fruit drop varies depending on the variety and application concentration. In the study, the application of AVG in the fruit size varied depending on the cultivars was effective. There were differences in the effect depending on the application concentration and cultivar. The highest fruit weight values were recorded in the trees treated with $225 \mathrm{mg} \mathrm{L}^{-1}$ AVG in both cultivar while the Redchief cultivar, there were the significant differences between applications, and the fruit weight was lower with the control application. However, in the Braeburn cultivar, the difference between applications was generally not significant, the smallest fruit were harvested on trees treated with $125 \mathrm{mg} \mathrm{L}^{-1}$ AVG. The supporting the study result, Phan-Thien et al. (2004), Greene (2006) and Petri et al. (2006) reported that the different results were obtained regarding the AVG effect on fruit size while Autio and Bramlage (1982) and Chun et al. (1997) determined that the effect of AVG on fruit weight may vary depending on the cultivar, application dose and ecological factors. However, it has been suggested that AVG significantly reduces fruit size in apples (Aglar et al., 2016), but has no significant effect on sweet cherry (Aglar et al., 2014).

With the progression of the fruit ripening, naturally SSC increases and acidity decreases, It is expected that AVG application, which delays fruit ripening with its effect on ethylene synthesis, has an effect that decreases SSC and increases acidity. The previous studies have shown the accuracy of this assumption. Thus Greene and Schupp (2004), Yildiz et al., (2012); Aglar et al., (2016) and Ozturk et al., (2019) reported that with AVG application, there was a decrease in the amount of SSC in the fruit and an increase in the acidity rate.

In the study, the effect of AVG application on fruit firmness was significant. The fruit with higher fruit firmness values were harvested on AVG-applied trees. The effect of AVG varied depending on the application concentration and the fruit frimness increased with the increase in the concentration. This is related to AVG inhibiting ethylene synthesis (Greene, 2006; Yildiz et al., 2012). In Apple (Byers, 1997; Greene, 2005; Amarante et al., 2002; Argenta et al., 2006; Greene, 2006; Yuan and Carbaugh, 2007; Yildiz et al., 2012; Aglar et al., 2016; Ozturk et al., 2019) and sweet cherry (Aglar et al., 2014; Koc Guler et al., 2019) have shown that AVG application is effective in maintaining the fruit firmness.

Starch index, which is an indicator of fruit maturity, also affects the fruit drop (Blanpied and Silsby, 1992). The bio-regulators such as AVG and Naphthalene acetic acid (NAA), which are used to prevent the fruit drop, slow down starch degradation (Byers, 1997; Greene, 2005; Yuan and Carbaugh, 2007). In the previous studies, it was reported that with AVG application, the starch degradation was delayed in apple cultivars such as, "Red Chief" (Yildiz et al., 2012), "McIntosh" (Stover et al., 2003) while Schupp and Greene (2004) suggested that the effect varies depending on the application concentration. In the study, there was a decrease in the amount of starch in the fruit with AVG application. However, it can be said that application concentration has not been significant in AVG effect.

As a result, AVG application had a positive effect on maintaining the fruit retention force and thus the fruit drop, but this effect varied depending on the cultivar and application concentration. The effect of AVG application on fruit size, SSC, acidity, fruit firmness and starch degradation was found to be significant. Considering the results of the study, the study revealed that AVG application can be used effectively to prevent pre-harvest fruit drop.

\section{CONFLICT OF INTEREST}

The authors declare that they have no conflict of interest.

\section{DECLARATION OF AUTHOR CONTRIBUTION}

EK and EA contribted to the planning, design, analysis of fruit and data analysis of experiment, and writing of the manuscript. 


\section{REFERENCES}

Addicott, F. (1982). Abscission, 1st ed. University of California Press, Berkeley.

Aglar, E., Long, L. E., Ozturk, B., Saracoglu, O., Yildiz, K., \& Karakaya, M. (2014). The efficacy of aminoethoxyvinylglycine (retain) for Improving fruit set on '0900 Ziraat' sweet cherry. Turkish Journal of Agricultural and Natural Sciences, 2, 1475-1478.

Aglar, E., Yildiz, K., Ozkan, Y., Ozturk, B., \& Erdem, H. (2016). The effects of aminoethoxyvinylglycine and foliar zinc treatments on pre-harvest drops and fruit quality attributes of Jersey Mac apples. Halil Erdem Scientia Horticulturae, 213, $173-178$.

Amarante, C. V. T. D., Simioni, A., Megguer, C. A., \& Blum, L. B. E. (2002). Effect of aminoethoxyvinilglycine (AVG) on preharvest fruit drop and maturity of apples. Revista Brasileira de Fruticultura, 24(3), 661-664.

Argenta, L. C., Vieira, M. J., Krammes, J. G., Petri, J. L., \& Basso, C. (2006). AVG and 1-MCP effects on maturity and quality of apple fruit at harvest and after storage. Acta Horticulturae, 727, 495-503.

Arseneault, M. H., \& Cline, J. A. (2016). A review of apple preharvest fruit drop and practices for horticultural management. Scientia Horticulturae, 211, 40-52.

Autio, W. R., \& Bramlage, W. J. (1982). Effects of AVG on maturation, ripening, and storage of apples. Journal of the American Society for Horticultural Science, 107, 1074-1077.

Bangerth, F. (2000). Abscission and thinning of young fruit and their regulation byplant hormones and bioregulators. Plant Growth Regulation, 31, 43-59.

Basak, A., \& Buczek, M. (2010). The effectiveness of 3, 5, 6-TPA used against pre-harvest fruit drop in apple. Proc. XI ${ }^{\text {th }}$ IS Plant Bioregulators Fruit Prod. Acta Horticulturae, 884, 215-222.

Blanpied, G. D., \& Silsby, K. J. (1992). Prediction of harvest date windows for apples. Cornell Cooperative Extension, 2212, 1-12.

Byers, R. E. (1997). Peach and nectarine fruit softening following aminoethoxyvinylglycine sprays and dips. HortScience, 32, 8688.

Chun, J., Park, M., Hwang, Y., \& Lee, J. (1997). Effect of AVG on harvest drop and fruitquality in 'Tsugaru' apples. Journal of Korean Society of Horticultural Science, 38, 147-152.

Dal Cin, V., Boschetti, A., Dorigoni, A., \& Ramina, A. (2007). Benzylaminopurineapplication on two different apple cultivars (Malus domestica) displays newand unexpected fruitlet abscission features. Annals of Botany, 99, 1195-1202.

Dal Cin, V., Danesin, M., Botton, A., Boschetti, A., Dorigoni, A., \& Ramina, A. (2008). Ethylene and preharvest drop: the effect of AVG and NAA on fruit abscission inapple (Malus domestica L. Borkh). Plant Growth Regulation, 56, 317-325.

Dal Cin, V., Barbaro, E., Danesin, M., Murayama, H., Velasco, R., \& Ramina, A. (2009). Fruitlet abscission: a cDNA-AFLP approach to study genes differentiallyexpressed during shedding of immature fruits reveals the involvement of aputative auxin hydrogen symporter in apple (Malus domestica L. Borkh). Gene, 442, 26-36.

Davies, P. J. (2010). Plant Hormones: Biosynthesis, Signal Transduction, Action, Springer, New York.

Drazeta, L., Lang, A., Hall, A .J., Volz, R. K., \& Jameson, P. E. (2004). Causes and effects ofchanges in xylem functionality in apple fruit. Annals of Botany, 93, 275-282.

Eccher, G., Begheldo, M., Boschetti, A., Ruperti, B., \& Botton, A. (2015). Roles ofethylene production and ethylene receptor expression in regulating applefruitlet abscission. Plant Physiology, 169, 125-137.

Estornell, L. H., Agustí, J., Merelo, P., Talón, M., \& Tadeo, F. R. (2013). Elucidating mechanisms underlying organ abscission. Plant Science, 199-200, 48-60.

Ferrero, S., Carretero-Paulet, L., Mendes, M. A., Botton, A., Eccher, G., Masiero, S., \& Colombo, L. (2015). Transcriptomic signatures in seeds of apple (Malusdomestica L. Borkh) during fruitlet abscission. PLoS One, 10, 1-15.

Greene, D. W., Kaminisky, K., \& Sincuk, J. (1987). An evaluation of stop drop materials in 1986. Proceedings Massachusetts Fruit Growers Association, 93, 74-78.

Greene, D. W., \& Schupp, J. R. (2004). Effect of aminoethoxyvinylglycine (AVG) on preharvest drop, fruit quality, and maturation of 'McIntosh' apples. II. Effect of timing and concentration relationships and spray volume. HortScience, 39, $1036-1041$.

Greene, D. W. (2005). Time of Aminoethoxyvinylglycine applications influences preharvest drop and fruit quality of Mclntosh' apples. HortScience, 40(7), 2056-2060.

Greene, D. W. (2006). An update on preharvest drop control of apples with aminoethoxyvinylglycine (ReTain). Acta Horticulturae, 727, 311-319. 
Küçüker and Ağlar, The Effect of Aminoethoxyvinylglycine (Avg) on Pre-Harvest Fruit Drop and Fruit Quality in Red Chief and Braeburn Apple Cultivars

Greene, D. W., Krupa, J., \& Autio, W. (2014). Factors influencing preharvest drop ofapples. Proc. XIth IS Plant Bioregulators Fruit Prod, Acta Horticulturae, 1042, 231-236.

Greene, D. W., \& Schupp, J. R., (2004). Effect of aminoethoxyvinylglycine (AVG) on preharvest drop, fruit quality, and maturation of 'McIntosh' apples. II. Effect of timing and concentration relationships and spray volume. HortScience 39, $1036-1041$.

Hong, S., Sexton, R., \& Tucker, M. L. (2000). Analysis of gene promoters for two tomato polygalacturonases expressed in abscission zones and the stigma. PlantPhysiol, 123, 869-881.

Huai, Q., Xia, Y., Chen, Y., Callahan, B., Li, N., \& Ke, H. (2001). Crystal structures of 1-aminocyclopropane-1-carboxylate (ACC) synthase in complex with aminoethoxyvinylglycine and pyridoxal-5_-phosphate provide new insight into catalytic mechanisms. Journal of Biological Chemistry, 276, 38210-38216.

Kang, I., Byun, J., Kweon, H., Kim, M., Kwon, S., Park, M., Lee, D. H., Choi, C., \& Choi, D. G. (2007). Effects of aminoethoxyvinylglycine on preharvest drop, fruit colour, and quality of 'Tsugaru' Apples. Horticulture, Environment, and Biotechnology, 48, 159-164.

Koc Güler, S., Karakaya, O., Karakaya, M. Ozturk, B., Aglar, E., Yarılgac, T., \& Gun, S. (2019). Combined treatments of modified atmosphere packaging with aminoethoxyvinylglycine maintained fruit quality in sweet cherry throughout cold storage and shelf life. Acta Scientiarum Polonorum Hortorum Cultus, 18(5), 13-26.

McFadyen, L., Robertson, D., Sedgley, M., Kristiansen, P., \& Olesen, T. (2012). Effects of the ethylene inhibitor aminoethoxyvinylglycine (AVG) on fruit abscission and yield on pruned and unpruned macadamia trees. Scientia Horticulturae, 137, 125-130.

Meir, S., Philosoph-Hadas, S., Riov, J., Tucker, M.L., Patterson, S. E., \& Roberts, J. A. (2019). Re-evaluation of the ethylenedependent and -independent pathways in the regulation of floral and organ abscission. Journal of Experimental Botany, $70,1461-1467$

Miqueloto, A., Amarante, C. V. T. D., Steffens, C. A., dos Santos, A., \& Mitcham, E. (2014). Relationship between xylem functionality, calcium content and the incidenceof bitter pit in apple fruit. Scientia Horticulturae, 165, 319-323.

Miranda, C., Santesteban, L. G., Royo, J. B. (2005). Removal of the most developedflowers influences fruit set, quality, and yield of apple clusters. HortScience, 40, 353-356.

Ozkan, Y., Ozturk, B., \& Yıldız, K. (2016). Effects of aminoethoxyvinylglycine and naphthaleneacetic acid on ethylene biosynthesis, pre-harvest fruit drop and fruit quality of apple. Pakistan Journal of Agricultural Sciences, 53(4), 893-901.

Ozturk, B., Ozkan, Y., \& Yildiz, K. (2015). AVG application regimes play an important role on pre-harvest drop and ripening of 'Jonagold' apples. Semina Ciências agrárias, 36, 3595-3604.

Ozturk, B., Yildiz, K., Erdem, H., Karakaya, O., Ozturk, A., \& Aglar, E. (2019). Aminoethoxyvinylglycine and foliar zinc treatments play a key role in pre-harvest drops and fruit quality attributesof 'william's prıde' apple. Acta Scientiarum Polonorum Hortorum Cultus, 18(2) 2019, 147-158.

Petri, J. L., Leite, G. B., Argenta, L. C., \& Basso, C. (2006). Ripening delay and fruit dropcontrol in 'Imperial Gala' and 'Suprema' ('Fuji Sport') apples by applying AVG (Aminoethoxyvinylglicine). Acta Horticulturae, 727, 519-526.

Phan-Thien, K. Y., Wargo, J. M., Mitchell, L. W., Collett, M. G., \& Rath, A. C. (2004). Delay inripening of 'Gala' and 'Pink Lady' apples in commercial orchards following pre-harvest applications of aminoethoxyvinylglycine. Australian Journal of Experimental Agriculture, 44, 807-812.

Polat, R., Güner, M., Dursun, E., Erdoğan, D., Gezer I., \& Bilim, C. (2007). Badem meyvesinin mekanik hasadı. Tarımsal Mekanizasyon 24. Ulusal Kongresi, Kahramanmaraş.

Robinson, T., Hoying, S., lungerman, K., \& Kviklys, D. (2010). AVG combined with pre-harvest drop of 'Mclntosh' apples better than either chemicalalone. Proc. XIth IS Plant Bioregulators Fruit Prod. Acta Horticulturae, 884, 343-350.

Schupp, J. R., \& Greene, D. W., (2004). Effect of aminoethoxyvinylglycine (AVG) on preharvest drop, fruit quality, and maturation of 'McIntosh' apples. I. Concentration and timing of dilute applications of AVG. HortScience, 39, 1030-1035.

Souzaa, K. O., Silveira, A. G., Lopes, M. M. A., Moura, C. F. H., Silva, E. O., Ayala-Zavala, J. F., Soares, L. S. P., \& Miranda, M. R. A. (2019). AVG and GA3 prevent preharvest fruit drop and enhance postharvest quality of 'BRS 189' cashew. Scientia Horticulturae, 257, 108771.

Stover, E., Fargione, M. J., Watkins, C. B., Lungerman, \& K. A. (2003). Harvest management of 'Marshall Mclntosh' apples: Effects of AVG, NAA, ethephon, and summer pruning on preharvest drop and fruit quality. HortScience, 38, 1093-1099.

Thompson, D. S., \& Osborne, D. J. (1994). A role for the stele in intertissue signaling inthe initiation of abscission in bean leaves (Phaseolus vulgaris L.). Plant Physiology, 105, 341-347. 
Küçüker and Ağlar, The Effect of Aminoethoxyvinylglycine (Avg) on Pre-Harvest Fruit Drop and Fruit Quality in Red Chief and Braeburn Apple Cultivars

Vriezen, W. H., Feron, R., Maretto, F., Keijman, J., \& Mariani, C. (2008). Changes intomato ovary transcriptome demonstrate complex hormonal regulation offruit set. New Phytologist, 177, 60-76.

Ward, D. L. (2004). Factors Affecting Preharvest Fruit Drop of Apple. PhD. Thesis. Virginia Polytechnic Institute and State University Blacksburg, Virginia, USA.

Yildiz, K., Ozturk, B., \& Ozkan, Y. (2012). Effects of aminoethoxyvinylglycine (AVG) on preharvest fruit drop, fruit maturity, and quality of 'Red Chief' apple. Scientia Horticulturae, 144, 121-124.

Yuan, R., \& Carbaugh, D. (2007). Effects of NAA, AVG, and 1-MCP on ethylene biosynthesis preharvest fruit drop, fruit maturity and quality of 'GoldenSupreme' and 'Golden Delicious' apples. Hortscience, 42, 101-105. 